
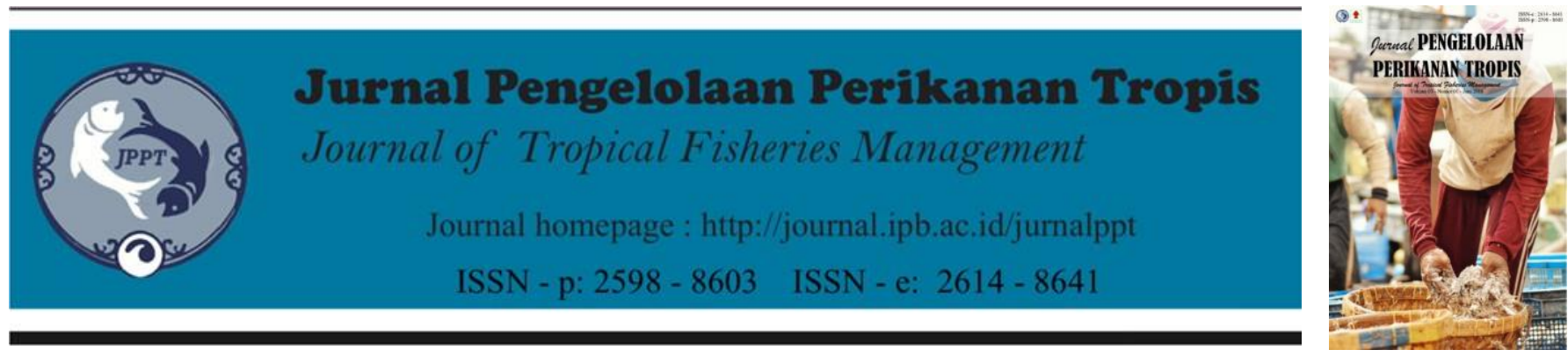

\title{
Keterkaitan Kematangan Gonad Ikan Selar Kuning (Selaroides leptolepis Cuvier, 1833) Dengan Suhu Permukaan Laut Di Perairan Selat Sunda
}

\author{
(The Relationship of Maturity of Yellowstripe Scad (Selaroides leptolepis Cuvier, 1833) with Sea Surface \\ Temperature in Sunda Strait Waters)
}

\author{
Muhamad Bisri Mustofa*, Isdrajad Setyobudiandi \\ Departemen Manajemen Sumberdaya Perairan, Fakultas Perikanan Dan Ilmu Kelautan, Institut Pertanian Bogor \\ Jl. Agatis, Kampus IPB Dramaga, Bogor, Jawa Barat, Indonesia
}

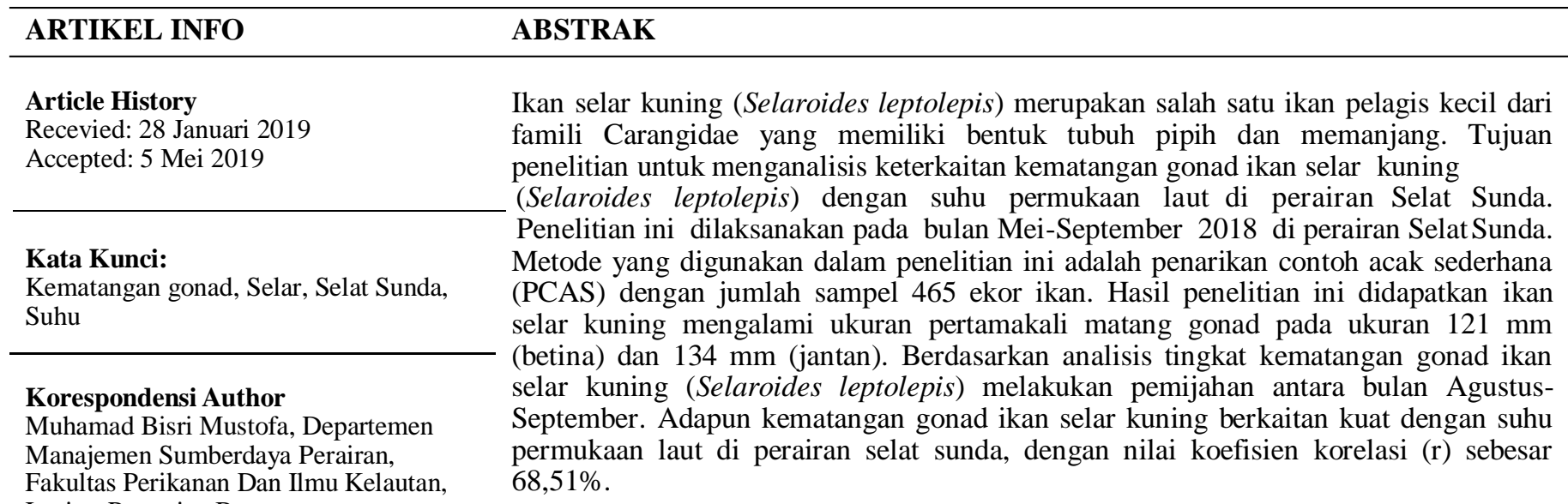

mu Kelautan,

Institut Pertanian Bogor

E-mail :

muhamadbisrimustofa17@gmail.com

\section{PENDAHULUAN}

Ikan selar kuning (Selaroides leptolepis) merupakan salah satu ikan pelagis kecil dari famili Carangidae yang memiliki bentuk tubuh pipih dan memanjang. Ikan ini merupakan ikan pelagis kecil yang hidup di kolom perairan. Menurut Sharfina (2014), ikan selar kuning merupakan salah satu komoditas perikanan yang bernilai ekonomis penting di perairan Selat Sunda. Jenis ikan selar kuning ini banyak dimanfaatkan sebagai ikan pindang, ikan bakar, ikan asin, juga diperdagangkan dalam keadaan segar maupun dibekukan. Tingginya minat masyarakat terhadap ikan selar kuning ini mendorong banyak pelaku perikanan untuk mengeksploitasi sumberdaya ikan ini tanpa memperhatikan keberlanjutan dari kegiatan tersebut. Jika hal ini terjadi secara terus menerus, akan mengkhawatirkan ketersediaan sumberdaya ikan ini di perairan.

Ketersediaan sumberdaya ikan selar kuning di perairan ini dapat diketahui melalui kajian reproduksi ikan tersebut. Ikan melakukan reproduksi dengan tujuan dasar untuk memperbanyak dan mempertahankan kelompoknya di perairan. Melalui aspek reproduksi ini kita dapat mengetahui jumlah telur yang dihasilkan dalam sekali memijah, pola pemijahan, dan musim ikan memijah. Keberhasilan ikan memijah dan kehidupan telur pasca dipijahkan oleh indukan ikan dapat dipengaruhi oleh faktor internal dan faktor eksternal termasuk rasio kelamin. Penelitian Prasetyanityas (2015) di Labuan diketahui bahwa keberhasilan tinggi karena rasio kelamin yang relative seimbang yaitu 1:1. Faktor internal biasanya berupa penyakit juga gen dari indukan, sedan gkan faktor eksternal berupa kondisi lingkungan perairan. Salah satu faktor eksternal yang berperan cukup penting dalam kehidupan ikan adalah suhu perairan.

Suhu merupakan faktor pengatur fisik mendasar dalam kehidupan ikan dan memiliki pengaruh besar terhadap proses reproduksi ikan mulai dari pengembangan gamet dan pematangan, ovulasi dan spermiasi, pemijahan, embriogenesis 
dan penetasan, perkembangan larva dan juvenil, serta kelangsungan hidup (Pankhurst dan Munday 2011). Suhu memiliki dampak yang cukup besar terhadap biota hidup di perairan salah satunya ikan. Ikan sendiri merupakan jenis hewan berdarah dingin yang artinya suhu tubuh ikan akan mengikuti suhu di sekitarnya, sehingga ketika terjadi perubahan suhu lingkungan sekitar maka suhu tubuh ikan akan berubah mengikuti suhu lingkungannya (Deniro et al. 2017).

Penelitian ini bertujuan untuk menganalisis ukuran pertama kali matang gonad (Lm), tingkat kematangan gonad (TKG), dan keterkaitan kematangan gonad ikan selar kuning (Selaroides leptolepis) dengan suhu permukaan laut di perariran Selat Sunda.

\section{METODE}

\section{Waktu dan Lokasi}

Penelitian ini di dilaksanakan pada bulan Mei hingga September 2018 di PPP Lempasing, Lampung (Gambar 1). Pengumpulan data ikan selar kuning (Selaroides leptolepis) menggunakan metode penarikan contoh acak sederhana (PCAS) dengan jumlah sampel 465 ekor ikan. Ikan contoh yang telah diambil kemudian diawetkan menggunakan formalin $10 \%$. Selanjutnya ikan contoh dibawa ke laboratorium Biologi Perikanan, Fakultas Perikanan dan Ilmu Kelautan, Institut Pertanian Bogor untuk dilakukan analisis. Data suhu permukaan laut perairan Selat Sunda diambil dari citra satelit Aqua MODIS (Moderate Resolution Imaging Spectroradiometer) level-3 dengan resolusi $4 \mathrm{~km}$ dari web oceancolor.gsfc.nasa.gov yang dikembangkan oleh NASA (2018). Data suhu permukaan laut yang sudah didapat kemudian diolah menggunakan software SeaWiFS Data Analysis System (SeaDAS) 7.5.3 untuk mendapatkan suhu permukaan laut di perairan Selat Sunda.

\section{Analisis Data}

Pengamatan ukuran pertama kali matang gonad $\left(\mathrm{L}_{\mathrm{m}}\right)$ diduga menggunakan metode Spearman-Karber (Udupa 1986) dengan persamaan sebagai berikut:

$$
\mathrm{m}=\left[\mathrm{X}_{\mathrm{k}}+\left(\frac{\mathrm{x}}{2}\right)-\left[\mathrm{X} \Sigma \mathrm{P}_{\mathrm{i}}\right]\right]
$$

dengan Lm (ukuran pertama kali matang gonad) adalah antilog dari $\mathrm{m}$.

Adapun pengamatan tingkat kematangan gonda dilakukan secara morfologi, dan penentuan tingkat kematangan gonad (TKG) didasarkan pada tabel TKG menurut Tandon (1960).

Hubungan antara suhu perairan dengan reproduksi dilakukan untuk melihat korelasi (r) menggunakan metode regresi linear sederhana (RLS) yang dikembangkan oleh Walpole (2001). Adapun persamaan nya adalah sebagai berikut:

$$
\mathrm{Y}=\mathrm{ax}+\mathrm{b}
$$

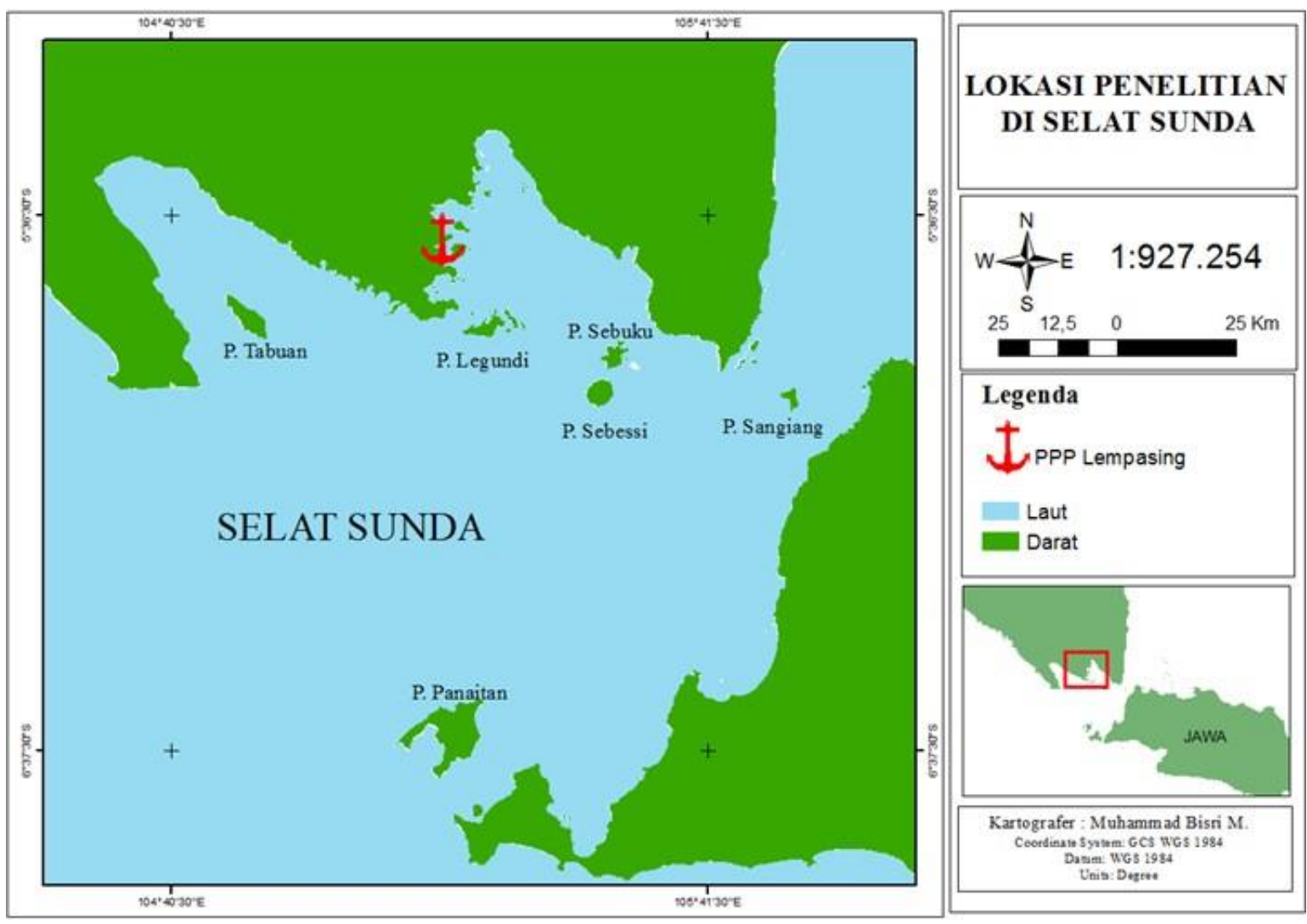

Gambar 1 Lokasi penelitian 
Tabel 1 Tingkat kematangan gonad ikan selar kuning (Tandon 1960)

\begin{tabular}{lll}
\hline \multicolumn{1}{c}{ TKG } & \multicolumn{1}{c}{ Betina } & \multicolumn{1}{c}{ Jantan } \\
\hline I. Belum matang & $\begin{array}{l}\text { Ovarium kecil, berwarna merah muda, dan } \\
\text { telur tidak terlihat }\end{array}$ & $\begin{array}{l}\text { Ukuran testes kecil, dan terlihat } \\
\text { seperti benang }\end{array}$ \\
\hline II. Hampir Matang & $\begin{array}{l}\text { Gonad menempati 1/2 rongga tubuh, gonad } \\
\text { tembus cahaya, butir telur dapat terlihat, } \\
\text { kuning telur terlihat }\end{array}$ & $\begin{array}{l}\text { Ukuran lebih besar, dan hampir } \\
\text { memenuhi rongga tubuh }\end{array}$ \\
\hline III. Mulai Matang & $\begin{array}{l}\text { Gonad menempati 3/4 rongga tubuh, gonad } \\
\text { tidak tembus cahaya, sebagian telur berukuran } \\
\text { besar sebagian berukuran kecil dan berwarna } \\
\text { kuning seulas }\end{array}$ & $\begin{array}{l}\text { Warna terlihat putih pekat, ukuran } \\
\text { lebih besar }\end{array}$ \\
\hline IV. Matang & $\begin{array}{l}\text { Gonad sudah memenuhi rongga tubuh, telur } \\
\text { berukuran besar, berwarna kuning keemasan, } \\
\text { penuh dengan kuning telur }\end{array}$ & Gonad memenurhi rongga tubuh \\
\hline V. Pemijahan & $\begin{array}{l}\text { Gonad telur membesar, kuning telur hampir } \\
\text { transparan dan mencapai diameter maksi- } \\
\text { mum, dan memiliki lapisan minyak }\end{array}$ & - \\
& &
\end{tabular}

VI. Dihabiskan

Ovarium terlihat seperti tahap ke II.

Keterangan

Y : Reproduksi

$\mathrm{X}$ : Suhu perairan

a : Intercept

b : Slope

\section{HASIL DAN PEMBAHASAN}

\section{Hasil}

Analisis ukuran pertama kali matang gonad (Lm) dilakukan untuk menduga ukuran ikan pada saat pertama kali matang gonad. Berdasarkan hasil analisis didapatkan hasil ikan selar kuning jantan pada penelitian ini mulai matang gonad pada ukuran 134,1718 mm, sedangkan pada ikan betina mulai matang gonad pada ukuran 121,9812 mm. Berikut ini (Gambar 2 dan 3) merupakan grafik ukuran pertama kali matang gonad ikan selar kuning (Selaroides leptolepis).

Tingkat kematangan gonad (TKG) adalah tahap perkembangan gonad ikan sebelum dipijahkan. Tingkat kematangan gonad (TKG) ditentukan secara morfologi mengacu pada tabel klasifikasi TKG Tandon (1960). Gambar 4 dan 5 merupakan grafik tingkat kematangan gonad (TKG) ikan selar kuning berdasarkan waktu pengambilan contoh.

Berdasarkan Gambar 4 ikan yang diambil pada bulan Mei didominasi oleh ikan jantan dengan TKG II sebanyak 29 ekor. Ikan yang diambil pada bulan Juni didominasi oleh ikan jantan dengan TKG II sebanyak 29 ekor. Ikan yang diambil pada bulan Juli didominasi oleh ikan jantan dengan TKG I sebanyak 28 ekor. Ikan yang diambil pada bulan Agustus didominasi oleh ikan jantan dengan TKG III sebanyak 10 ekor.
Ikan yang diambil pada bulan September didominasi oleh ikan jantan dengan TKG I dan TKG II, masing-masing 16 ekor.

Berdasarkan Gambar 5 ikan yang diambil pada bulan Mei didominasi oleh ikan betina dengan TKG I sebanyak 39 ekor. Ikan yang diambil pada bulan Juni didominasi oleh ikan betina dengan TKG II sebanyak 15 ekor. Ikan yang diambil pada bulan Juli didominasi oleh ikan betina dengan TKG IV sebanyak 23 ekor. Ikan yang diambil pada bulan Agustus didominasi oleh ikan betina dengan TKG IV sebanyak 7 ekor. Ikan yang diambil pada bulan September didominasi oleh ikan betina dengan TKG II sebanyak 21 ekor.

Analisis hubungan antara suhu dengan reproduksi ikan ini dilakukan untuk menduga apakah reproduksi ikan dipengaruhi oleh suhu perairan. Hubungan antara keduanya dilihat dari nilai koefisien korelasi (r) dan koefisien determinasi $\left(\mathrm{R}^{2}\right)$. Berikut merupakan tabel hubungan antara suhu dengan reproduksi ikan (Tabel 2).

Berdasarkan Tabel 2 diketahui suhu permukaan laut mengalami penurunan pada saat bulan pengambilan sampel. Penurunan suhu tersebut kemudian diikuti dengan meningkatnya jumlah persentase ikan yang sudah matang gonad, berbeda dengan bulan September suhu permukaan laut tetap turun dan diikuti penurunan jumlah persentase ikan yang sudah matang gonad. Hal ini diduga antara bulan Agustus-September telah terjadi puncak pemijahan. Adapun hubungan keeratan antara suhu permukaan laut dengan reproduksi ikan dapat dikatakan kuat dengan nilai $r=68,51$. 


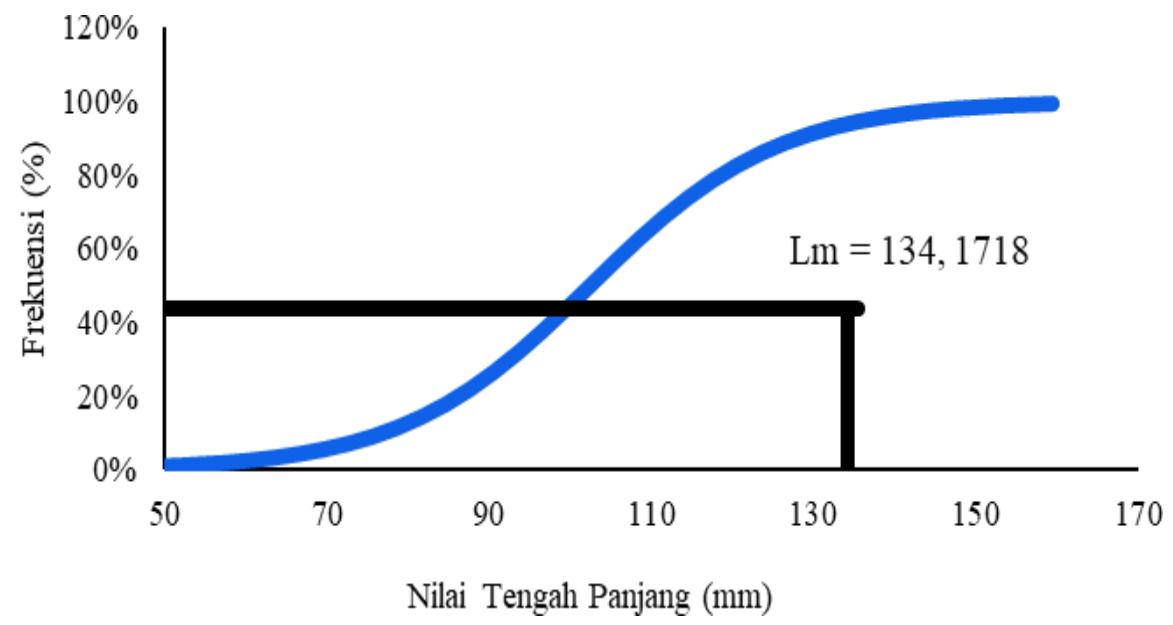

Gambar 2 grafik ukuran pertamakali matang gonad ikan selar kuning (Selaroides leptolepis) jantan

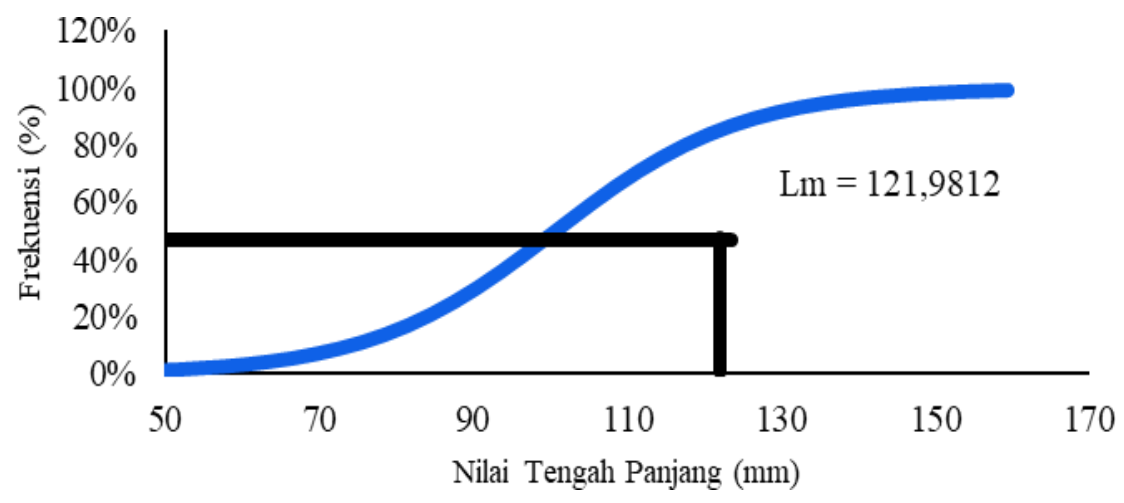

Gambar 3 grafik ukura pertamakali matang gonad ikan selar kuning (Selaroides leptolepis) betina

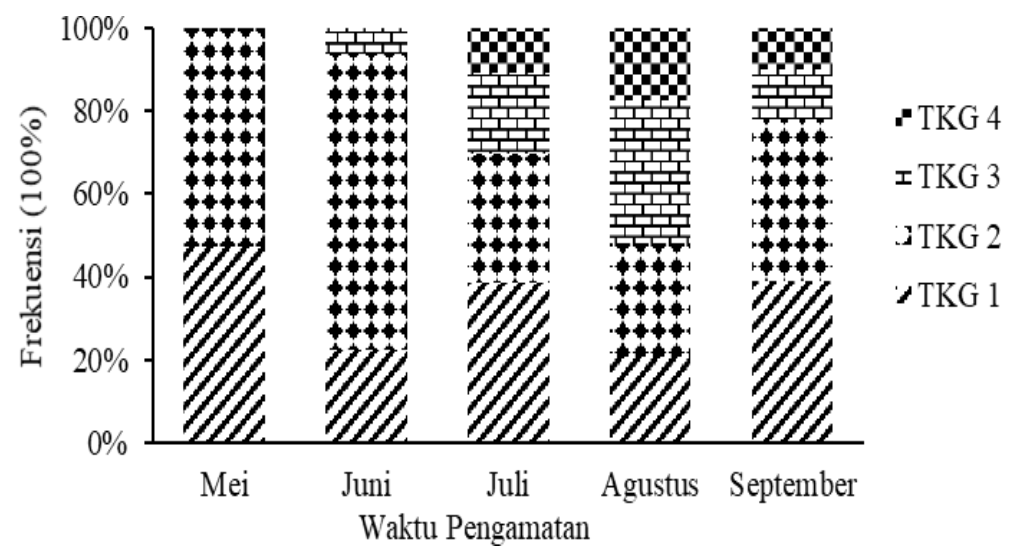

Gambar 4 Frekuensi tingkat kematangan gonad ikan selar kuning (selaroides leptolepis) jantan

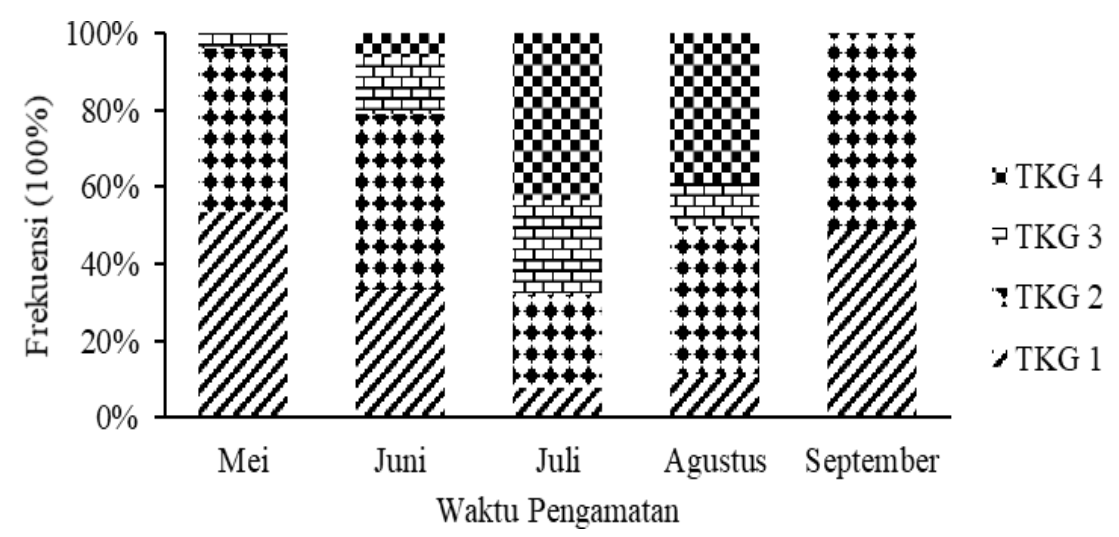

Gambar 5 Frekuensi tingkat kematangan gonad ikan selar kuning (selaroides leptolepis) betina 
Tabel 2 Hubungan antara suhu dengan reproduksi

\begin{tabular}{lcccccc}
\hline \multirow{2}{*}{ Parameter } & \multicolumn{5}{c}{ Bulan } & \multirow{2}{*}{ (r) } \\
\cline { 2 - 5 } & Mei & Juni & Juli & Agustus & September & \\
\hline Mature (\%) & 2,3 & 17,44 & 47,54 & 51,03 & 10,97 & \multirow{2}{*}{68,51} \\
Suhu & 30,08 & 29,77 & 28,54 & 28,38 & 28,27 & \\
\hline
\end{tabular}

\section{Pembahasan}

Ukuran pertama kali matang gonad dianalisis untuk menduga ukuran ikan pertama kali saat matang gonad. Menurut Gandhi et al. (2014), penentuan ukuran pertama kali matang gonad dilakukan untuk menghindari terjadinya penangkapan yang berlebihan pada ikan yang belum matang gonad. Hossain et al. (2012) menambahkan bahwasannya ukuran matang gonad dijadikan sebagai ukuran minimum untuk kegiatan penangkapan yang diperbolehkan. Berdasarkan hasil analisis didapatkan hasil ikan selar kuning jantan matang gonad pada ukuran $134 \mathrm{~mm}$, sedangkan ikan betina matang gonad pada ukuran $121 \mathrm{~mm}$ (Gambar 2 dan 3). Berdasarkan hasil tersebut, ikan selar kuning betina mengalami matang gonad lebih cepat dibandingkan ikan jantan. Hal ini selaras dengan penelitian yang dilakukan oleh Prestianingtyas (2015), Ilfaroza (2016), dan Nirtawa (2016).

Menurut Sulistiono et al. (2001), perbedaan ukuran pertama kali matang gonad pada ikan jantan dan betina dapat disebebkan oleh parameter pertumbuhan yang berbeda-beda. Hal ini sesuai dengan pernyataan Udupa (1986) yang menyatakan bahwa individu dari satu kelas panjang yang sama tidak selalu mencapai panjang pertama kali matang gonad pada ukuran sama karena ukuran pertama kali matang gonad sangat bervariasi dalam jenis ikan itu sendiri. Lagler et al. (1977) in Zenty (2018) menambahkan bahwa terdapat dua faktor yang mempengaruhi saat ikan pertama kali matang gonad, yaitu faktor internal dan faktor eksternal. Adapun faktor internal yang dimaksud adalah perbedaan spesies, umur, ukuran, serta sifat fisiologi ikan tersebut seperti kemampuan adaptasi terhadap lingkungan dan perbedaan jenis kelamin.

Tingkat kematangan gonad (TKG) merupakan tahap perkembangan gonad ataupun kondisi gonad sebelum dipijahkan. Hasil penelitian ini menunjukkan ikan selar kuning yang sudah matang gonad umumnya ditemukan pada bulan Juli-Agustus. Sehingga diduga bahwa ikan selar kuning di perairan selat sunda ini memijah antara bulan Agustus-September. Hasil ini berbeda dengan hasil penelitian Tasri (2017) yang dilakukan di perairan Subang, Jawa Barat. Hasil penelitian Tasri (2017) menunjukkan bahwa ikan selar kuning di perairan Subang memijah antara bulan Desember-Februari. Menurut Keown dan Brian (1984) in Tasri (2017) ada beberapa faktor yang menjadi penyebab perbedaan kematangan gonad ikan yaitu morfologi, tingkah laku, maupun fisiologis ikan.

Suhu rata-rata di perairan Selat Sunda pada saat pengambilan sampel (Mei-September) umunya berkisar antara $28-31^{\circ} \mathrm{C}$ (Tabel 2). Suhu rata-rata perairan selama penelitian dilakukan mengalami penuruan pada setiap bulannya. Penurunan suhu perairan yang terjadi diikuti dengan meningkatnya persentase jumlah ikan yang sudah matang gonad (Tabel 2). Akan tetapi berbeda pada bulan September, suhu perairan pada bulan tersebut tetap menurun dan persentase jumlah ikan matang gonad juga menurun. Hal ini diduga antara bulan Agustus-September terjadi puncak pemijahan, sehingga persentase jumlah ikan matang gonad sedikit. Berdasarkan hasil analisis hubungan antara suhu perairan dengan reproduksi ikan didapatkan nilai koefisien korelasi $(r)=68,51 \%$, artinya hubungan keduanya dapat dikatakan kuat.

\section{KESIMPULAN}

Ikan selar kuning mengalami pertama kali matang gonad pada ukuran $121 \mathrm{~mm}$ (betina) dan $134 \mathrm{~mm}$ (jantan). Ikan selar kuning memijah antara bulan Agustus-September. Adapun kematangan gonad ikan selar kuning berkaitan kuat dengan suhu permukaan laut di perairan selat sunda, dengan nilai koefisien korelasi (r) sebesar $68,51 \%$.

\section{DAFTAR PUSTAKA}

[NASA] National Aeronautics And Space Administration. 2018. Ocean Color Feature. [internet] [diakses 3 September 2018]. Tersedia di https:// Oceancolor.Gsfc.Nasa.Gov/

Deniro, Sadarun, Yusnaini. 2017. Pengaruh kenaikan suhu air laut terhadap tingkah laku ikan Karang (Amblyglyphidodon curacao) pada wadah terkontrol. Sapa Laut. 2(3): 6167

Gandhi V, Venkatesan V, Ramamoorthy N. 2014 Reproductive biology of the spotted scat Scatophagus argus (Linnaeus, 1766) from Mandapam waters, South-east coast of India. Indian J. Fish. 61(4):55-59.

Deniro, Sadarun, Yusnaini. 2017. Pengaruh 
naikan suhu air laut terhadap tingkah laku ikan Karang (Amblyglyphidodon curacao) pada wadah terkontrol. Sapa Laut. 2(3): 6167.

Gandhi V, Venkatesan V, Ramamoorthy N. 2014 Reproductive biology of the spotted scat Scatophagus argus (Linnaeus, 1766) from Mandapam waters, South-east coast of India. Indian J. Fish. 61(4):55-59

Hossain MY, Mosaddequr R, Elgorban MA. 2012. Relationships between body size, weight, condition and fecundity of the Threatened fish (Puntius Ticto Hamilton, 1822) in the Ganges River, Northwestern Bangladesh. Sains Malaysiana. 41(7): 803-814

Ilfaroza M. 2016. Biologi reproduksi ikan Selar kuning (Selaroides leptolepis Cuvier, 1833) di perairan Selat Sunda. [Skripsi]. Institut Pertanian Bogor.

Nirtawa. 2016. Dinamika populasi ikan Selar kuning (Selaroides leptolepis Cuvier, 1833) di perairan Selat Sunda. [Skripsi]. Institut Pertanian Bogor.

Pankhurst NW, Munday PL. 2011. Effects of climate change on fish reproduction and early life history stages. Marine and Freshwater Research. 62: 1015-1026.

Presetianingtyas R. 2015. Aspek biologi reproduksi ikan selar Kuning (Selaroides leptolepis Cuvier, 1833) di perairan Selat Sunda, Provinsi Banten. [Skripsi] Institut Pertanian Bogor.

Sharfina M. 2014. Dinamika populasi dan biologi reproduksi ikan Selar Kuning (Selaroides leptolepis) di perairan Selat Sunda. [Tesis] . Institut Pertanian Bogor.

Sulistiono, Jannah MR, Ernawati Y. 2001. Reproduksi ikan Belanak (Mugil dussumeiri) di perairan Ujug Pangkah, Jawa Timur. Jurnal Iktiologi Indonesia. 1(2):31-37.

Tandon KK. 1960. On the biologi and fishery of 'Choo parai' - Selaroides leptolepis. [Disertasi]. Panjab University.

Tasri H. 2017. Aspek biologi reproduksi ikan selar kuning (Selaroides leptolepis Cuvier, 1833) di Blanakan, Subang, Jawa Barat. [Skripsi]. Institut Pertanian Bogor

Udupa KS. 1986. Statistical method of estimating the size at first maturity in fishes. Fishbyte. 4 (8): 8-10.

Walpole, RE., (1995), Pengantar Statistika, edisi ke-3, Penerbit PT. Gramedia Pustaka Utama

Zenty I. 2018. Biologi reproduksi ikan Layur (Trichurus leptulus Linnaeus,1758) di Teluk Palabuhanratau, Sukabumi, Jawa Barat. [Skripsi]. Institut Pertanian Bogor 